\title{
Quantitative ethnobotanical study of medicinal flora used by local inhabitants in selected Barangay of Malinao, Albay, Philippines
}

\author{
TERESA HAIDE R. BELGICA ${ }^{1,2, \boldsymbol{v}}$, MARLON D. SUBA ${ }^{3}$, GRECEBIO JONATHAN D. ALEJANDRO ${ }^{1,4}$ \\ ${ }^{1}$ The Graduate School, University of Santo Tomas. España Boulevard, 1015 Manila, Philippines. "email: thrbelgica@gmail.com \\ ${ }^{2}$ Sorsogon State College. Magallanes Campus, Magallanes, Sorsogon 4705, Philippines \\ ${ }^{3}$ College of Arts \& Sciences, Angeles University Foundation. Angeles City, Pampanga 2009, Philippines \\ ${ }^{4}$ College of Science \& Research Center for the Natural \& Applied Sciences, University of Santo Tomas. España Boulevard, 1015 Manila, Philippines
}

Manuscript received: 16 April 2021. Revision accepted: 14 June 2021

\begin{abstract}
Belgica THR, Suba MD, Alejandro CJD. 2021. Quantitative ethnobotanical study of medicinal flora used by local inhabitants in selected Barangay of Malinao, Albay, Philippines. Biodiversitas 22: 2711-2721. This study identified and documented herbal medicines used in traditional therapies of local inhabitants in Malinao Albay. Ethnobotanical documentation in this study was through field observation, unstructured interviews, group discussions, and guided field walks. Preference ranking, use-value, informant consensus factor, and fidelity level were quantified. Based on the survey, 74 medicinal plants from 38 families and 72 genera were identified by 350 local inhabitants with therapeutic purposes using quantitative ethnobotanical indices. The plant species belonging to Lamiaceae were best represented with eight species, followed by Compositae with six species and Euphorbiaceae, Malvaceae, and Moraceae with four species each. While the plant species, i.e., Senna alata (L.) Roxb and Pogostemon cablin (Blanco) Benth, were recorded with the highest Fidelity level (FL). In terms of Informant Consensus Factor (ICF), Justicia gendarussa Burm.f, Lagerstroemia speciosa (L.) Pers and Centella abbreviata (A. Rich.) Nannf were recorded with the highest values. Moreover, the plant with the highest Use Value (UV) was Moringa oleifera Lam, and the leaves were the most used part as a decoction to cure different illnesses. This study provides baseline data of plant diversity in Malinao Albay and their medicinal uses, which could be used as a basis for drug discovery to improve the utilization of herbal plants from global perspectives.
\end{abstract}

Keywords: Bicol region, conservation, Luzon, medicinal plants, volcano

\section{INTRODUCTION}

Medicinal plants grow naturally around us. Over centuries, cultures worldwide have learned how to use plants to fight diseases and maintain health benefits. These available and culturally important traditional medicines form the basis of an accessible and affordable health care regime and are an essential source of livelihood for indigenous and rural populations (Awoyemi et al. 2012). People across the world use herbal medicines to treat various illnesses. Several scientific investigations on herbal plants have been initiated in many countries because of their contribution to the healthcare system (WHO 2011).

Approximately $80 \%$ of the population around the world uses plants to treat several illnesses (World Health Organization 2014). Like in rural communities, people depend solely on plant-based medicines, whereas the modern healthcare system mainly depends on plant-based ingredients (Kumar et al. 2011). Furthermore, treatment with traditional folk medicines based on the use of plants by the local communities has been practiced for centuries. It travels through generations from older to younger ones, particularly among those who live in some isolated area where health services and even health practitioners are scarce (Aziz et al. 2018). In the Philippines, about 1500 medicinal plants from more than 13,500 plant species are known (Suba et al. 2019).
The Philippines was classified by WHO and other countries where traditional medicine has remained a vital element of the health care system despite having a wellestablished health care system (Birhane et al. 2011). The need for medicinal plants comes with the demand for an immediate cure for specific diseases and discomfort. This is more evident in remote areas which lack medical support and far from the urban community. Moreover, going to clinics and hospital require money for travel, appointment, and medicine. The "parahilot" in the Philippines greatly helps the locals by giving alternative solutions through medicinal plants to aid diseases and discomfort.

Due to technological advancement, these medicinal plants are being processed and is transformed into the capsule for commercialization, where locals can cultivate them in their backyard. An example of this is Blumea balsamifera L.(DC), commonly known as sambong, and Vitex negundo L., known as lagundi. These commercialized medicinal plants are effective; however, consumers may wonder about the processing of the product that may or may not contain impurities and contamination compared to a freshly picked medicinal plant (Mukherjee 2019). Unfortunately, these technological advancements have threatened biodiversity in many parts of the world.

The introduction of medicinal practices and modern plant medicines is considerably increased, resulting in the gradual replacement of traditional methods (Yuan et al. 2016). Thus, it contributes to anthropogenic disturbances 
such as deforestation, human infringement, agricultural needs, and strategic development; these factors could lead to an enormous risk of extinction of medicinal plants.

With the emerging threat of losing traditional knowledge in the modern era, researchers carried numerous efforts to record and publish this knowledge. Various studies have been conducted on ethnomedicinal knowledge worldwide, finding solutions to emerging diseases and health problems (Sofowora et al. 2013). Consequently, local communities' documentation of indigenous traditional medicinal plants is very significant to give opportunities for the discovery and development of inexpensive plant-based medicines.

The Province of Albay, Philippines is famously known to be rich with flora and cultural diversity due to its geographic location. It is mountainous and abounds with water resources such as rivers, lakes, natural springs, and waterfalls located in the Bicol region of Luzon. Most of the inhabitants live near/on mountains, plains, farmlands, and coastal areas leading a traditional way of life. Still, no comprehensive ethnobotanical studies have been carried out in the area except for the preliminary inventory of plants in different vegetation types of Mt. Malinao (De Guzman et al. 2014).

Therefore, preserving traditional knowledge and documentation of these herbal medicines is essential since both biological and cultural diversity face various threats. Thus, this study aims to identify the medicinal plants used by local inhabitants of selected barangays in the Municipality of Malinao.

\section{MATERIALS AND METHODS}

\section{Study area}

Malinao has a total land area of approximately 10,750 hectares or 107.5 square kilometers of the total land area of 2,552.6 hectares of Albay Province. The municipality was classified into lowland, coastal and upland areas. Topographically, the study area is mountainous with lush of diverse flora and fauna situated in the foothills of Mt. Malinao. This mountain is located in the southeastern island of Luzon, Philippines, about $20 \mathrm{~km}$ northwest of Mayon Volcano, located at 130"24' $34.6 \mathrm{~N}$ and longitude $123038^{\prime} 33.0 \mathrm{~W}$ latitude (Figure 1). Subsequently, the mountain has an elevation of $1,548 \mathrm{~m}$ and a $22.5 \mathrm{sq} . \mathrm{km}$ base circumference. Mountaineers frequently visit the long and narrow, thickly forested area of Mt. Malinao. It is a dormant volcano characterized by breached wall crater on the eastern side and a recorded temperature of $108^{\circ} \mathrm{C}$. There are about 29 barangays in the area, and among these, barangays, Bulang, Quinarabasahan, Sugcad, Comun, and Tagoytoy were identified as upland barangay. The identification was based on the criterion that they use plants and other plant products in the healing process and accessibility. Permits were also secured to conduct the study, such as, letter request to the local government unit of Malinao to collect samples and a consent letter from the local inhabitants.

\section{Informants selection}

The local inhabitants documented information on the use of plant resources (Knittel-Weber et al. 1990). The choice of the informants mainly included the member of the households, and older generations comprise of traditional healers, elderly age range from 20-95 years old, a long-time resident in the barangay, having a broader knowledge on the use of the plants as medicine or identified as a medicinal plant (Tongco 2013). Primarily, of the selected informants, 12 traditional medicinal practitioners locally known as parahilot, parasantigwar, and parahula were identified among a total of 350 key informants.

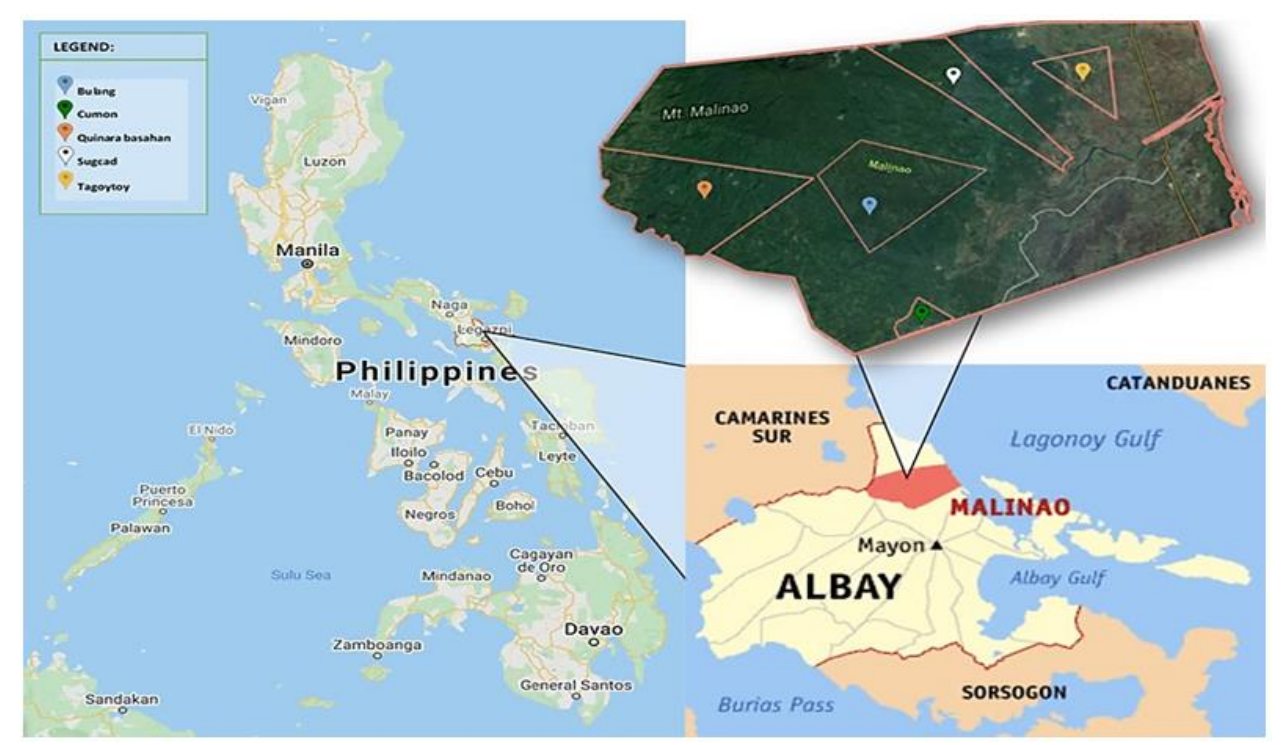

Figure 1. Map of the Philippines where Malinao Albay is located, the shaded green color map with marked are the sampling sites, i.e., Bulang, Cumon, Quinarabasahan, Sugcad, and Tagoytoy represented (Google Maps, 2020) 


\section{Field interviews}

The field surveys were undertaken for three months, from April 2016 to June 2016. Before the conduct of the study, secured ethical approval from the Ethics Review Committee of the University of Santo Tomas (UST), and informed permission was made through the local administrators of the Local Government Unit of Malinao. Likewise, acquired ethnobotanical information following the approved ethical standards. An ethnobotanical survey was done through interviews using semi-structured questionnaires, observation, and focus group discussions with informants of the local community. The questionnaire guide was written in English and translated into the Bicol dialect. According to Ong et al. (2014), semi-structured interviews allow researchers to gather a great deal of data from a large number of people in a relatively short period while leaving the interviewee at ease to answer the questions put to them. This approach allowed flexibility in the conversations and open exchanges with the informants (Schultz et al. 2020).

Each participant was asked about personal experiences or participation in the use and preparation of medicinal plants. Informants were interviewed on an informal basis to maximize the source of information and understand the people's traditional medicinal system and its medicinal uses. The data gathered comprises local vernacular names, part(s) used, mode of preparation, diseases treated, route of application, and other uses of medicinal plants are presented and summarized in Table 1. All medicinal plants identified were photo-documented right on their natural habitat during sampling, and initial identification was carried out during field walks with the local experts. Finally, in compliance with the research ethics protocol, the researchers obtained.

\section{Collection of plant specimen, voucher specimen preparation, and identification}

Collections of plant samples were conducted with the help of the informants on the identification of medicinal plants. Frequent field works were done to collect information about the folk/culinary knowledge of medicinal plants used by the local inhabitants in Malinao to cure various diseases. During field trips, the forest guides and the local inhabitants, including older men and women familiar with the traditional use of collected plants, were interviewed. Standards taxonomical procedures were considered in gathering medicinal plants. Collected plants were pressed between newspapers treated with denatured alcohol that was sandwiched in a wooden plant presser. Samples of the plant collected were oven-dried. Each dried plant specimen was mounted on white Bristol sheets $11.5 \mathrm{x}$ 16.5" using Polyvynilacetate (PVA) glue. This mounted specimen served as vouchers of medicinal plants with their taxonomic and ecological information. Voucher specimens were deposited at the UST-Herbarium. To validate the scientific names of collected plants; databases from Stuartxchange (2019), Co's Digital Flora of the Philippines (Pelser et al. 2011), the Plant List (2010), Tropicos (2020), and Plant of the World (2019) were used, and the curator at UST-Herbarium authenticated plants.

\section{Data analysis}

The data were analyzed and entered into the Microsoft Excel database 2016 software package. These variables included: total number of medicinal plants, number of botanical families, most reported medicinal uses, most commonly treated disease, the method of preparation, and mode of application. Furthermore, there were three ethnobotanical indices used to quantify the importance of medicinal plants: the use-value (UV), informant consensus factor (ICF), and fidelity level (FL). The UV was used to assess the relative importance of the species known locally using the formula: $U V=\Sigma U / n$, where $U$ is the number of citations per species, and $\mathrm{n}$ is the total number of informants (Newman et al. 2012). There is a high used value when many used reports for a single plant without regard to the number of disease categories, which indicate that plant is essential.

However, to show the homogeneity of the information collected and the degree of overall agreement on the treatment of specific health disorders category was calculated using the formula of Informant Consensus Factor (Trotter et al. 1986). This quantitative method investigates the effectiveness of medicinal plants on particular ailments using the formula: ICF $=\left(\mathrm{N}_{\mathrm{ur}}-\mathrm{N}_{\mathrm{t}}\right) /($ nur1) where $N_{u r}$ refers to the number of use citations in each category, $\mathrm{N}_{\mathrm{t}}$ refers to the number of plant species used for a particular category by all informants. To use these tools, the ailments are categorized. The ICF values range between 0 and 1 , while 0 indicates the lowest level of informants' consent. In contrast, 1 indicates the highest level (approaching 1) when only one or few plant species are reported to be used by the high proportion of informants in a particular disease category (Heinrich 2000). It indicates that plants with high ICF are likely to be more pharmacologically efficient than low ICF (Trotter et al. 1986). Informant Consensus Factor highlighted plants of particular cultural relevance and agreement in the use of plants within a community and between cultural groups, which indicates plants that are widely used and aid in identify particular interesting species for the bioactive compounds (Prasad et al. 2013).

Subsequently, the percentage of informants claiming the use of medicinal plants for similar major purposes were calculated for the most frequently reported diseases or ailments as follows: FL $(\%)=(\mathrm{Np} / \mathrm{N}) \times 100, \mathrm{~Np}$ is the number of the informant that claim plant species to treat a particular disease, and $\mathrm{N}$ is the number of informants mentioned using the plants as a medicine to treat any given disease (Alexiades 1996). Moreover, medicinal plant use was grouped into disease categories based on the WHO's International Classification of Disease (ICD-10) (World Health Organization 2020). Moreover, every time a plant was mentioned as being used for a particular purpose, considered to be one use report. Nevertheless, if one informant used a plant to treat an illness, more than one purpose under the same category was regarded as a single use-report (Dapar et al. 2020). The Fidelity level is useful for identifying the key informants' most preferred species used to treat certain illnesses. The medicinal plants that are widely used by the local people have higher FL values than 
those that are less popular. A high value indicates that a medicinal plant was considered the most preferred species by the informants for a particular category, and a low value indicates that many species were used in the same type. It is notable that those medicinal plants that are used in some recurring manner for the same disease category are more likely to be active biologically (Khan et al. 2014).

\section{RESULTS AND DISCUSSION}

\section{Demographic profile of respondents}

Demographic characteristics employed in the study were determined during interviews. A total of 350 informants were interviewed, comprised of 236 women. One hundred fourteen are men, 12 of whom were practicing as traditional healers. Respondents were divided into four categories, i.e. (1) 18-30, (2) 31-45, (3) 46-60, (4) 61-75 and over 75 years old, respectively. Out of 350 participants, 130 were elementary school graduates, 116 were high school, and 104 were college graduates. Interestingly, most informants from age 46-60 were mostly females who were more knowledgeable on traditional medicinal plants than male community members, as reflected in Table 1.

According to informants, they practiced the use of medicinal plants for therapeutic purposes. Besides, all of them reported that the knowledge of medicinal plants was passed from their ancestors. In comparison to male members, it was noticeable that female informants were more aware of the preparation and administration of folk medicines reflecting their roles in household management and first-hand treatment of disease to maintain their family's health (Braidotti et al. 1994).

The study of Abe and Ohtani (2013) in Batan Island proved that women play a significant role in preparing traditional medicines and medicinal plants in treating specific ailments. Indeed, differences in the knowledge held by women and men or gendered knowledge are considered to be one of the most significant sources of intra-cultural knowledge variation. In this study, most local inhabitants relied on traditional plant-based medicine due to the scarcity of healthcare facilities. The rich diversity and availability of medicinal resources in the community may influence the local people to utilize herbal medicines.

\section{Characteristics of medicinal flora}

Seventy-four species of medicinal plants belonging to 72 genera from 38 families were documented during the field survey (Table 1). Among the Families, Lamiaceae was the best represented with eight species, followed by Compositae with six species and Euphorbiaceae, Malvaceae, Moraceae with four species each, respectively. About $35 \%$ were herbs, $27 \%$ were trees, $24 \%$ were shrubs, $7 \%$ were ornamentals, and $7 \%$ were grasses (Figure 2). Moreover, out of the 74 medicinal plants collected, 44 plants with therapeutic value were collected in the wild. In contrast, 30 medicinal plants were cultivated, which showed that active compounds might be present in the wild population in which plants grow slowly (Balangcod et al.
2011). Hence, further investigations of these medicinal plants on chemical components are necessary.

Out of 74 collected plants, five of these were on the Department of Health (DOH) list as approved herbal medicine. These are Blumea balsamifera L.(DC), Senna alata (L.) Roxb. , Vitex negundo L, Peperomia pellucida L. Kunth, and Psidium guajava L. However, during the interview, different plants are sometimes given the same local name they commonly used for identification. Like in the case of Euphorbia hirta Linn, and Mussaenda frondosa L. were both known as "tawa-tawa." This indicates that there are possibilities that different plant species can be used in curing some diseases based on their same local names, which could be detrimental to the users.

\section{Plant part used}

Almost all parts of the medicinal flora, such as leaves, roots, fruits, flowers, rhizomes, sap, and barks, are essentials in treating various diseases (Ahmad et al. 2014). However, the most frequently used parts of the medicinal plants based on the survey were leaves at $80 \%$, and the least part was fruit at $1.33 \%$ (Figure 4).

Similar reports on the use of leaves were noted in previous ethnobotanical studies conducted in the Philippines (Friedman et al. 1996; Sing et al. 2012; Birendra et al. 2015). In addition to this, leaves are made readily available in the surroundings and considered active photosynthetic organs with many active compounds to synthesize most herbal medicines in high concentration (Obico et al. 2014; Odchimar et al. 2017). Moreover, inhabitants can quickly identify plants based on leaves. In contrast, roots are the most commonly used plant parts in treating illnesses in some ethnobotanical studies. However, using roots is more damaging to a particular plant than its leaves since plants should be uprooted (Tantengco et al. 2018). Subsequently, some of the plant parts are utilized to cure multiple ailments. For instance, the leaves of Centella abbreviata (A. Rich.) Nannf is used to cure cancer sore and colds. Other plant parts such as sap of Ficus benjamina Linn. are used for sprain, while Senna alata (L) Roxb. roots and leaves are utilized as a remedy against fungal infections and blisters.

\section{Herbal drug preparation and mode of administration}

A total of 40 illnesses were treated using medicinal plants (Table 1). About twenty-one species were used for skin diseases, 19 species for gastrointestinal, 14 species for respiratory, seven species for cardio-metabolic, three species for urinary disorders. The main methods of preparation for herbal drugs for these diseases were applied as a paste $(44 \%)$, decoction $(37 \%)$, as well as crushed $(15 \%)$, which directly applied onto the affected area to use as a wash for disinfecting wounds and skin diseases (2\%) (Figure 3). According to Giday (2003), the application as a paste is safest compared to the internal mode of administration because it allows easier regulation of dosages and administration of toxic compounds (Giday et al. 2003). The preparation can be done either with or without the combination of other plants or materials. In decoction, plant parts are boiled, or extracts are used 
internally to cure certain gastrointestinal and genitourinary diseases. For example, Andrographis paniculata (Burm.f.) Nees, Blumea balsamifera (L.) DC, Proiphys amboinensis (L.) Herb, for stomachache, Cymbopogon schoenanthus (L) Spreng, Kaempferia galangal L, Ficus pseudopalma Blanco for lowering blood pressure and the like. The inhabitants most frequently use this most commonly used preparation method because this is the easiest way to prepare, especially to cure internal ailments. Certain investigations indicated that infusion and decoction might be consistent with phytopharmacological effects that plants subjected to these processes have higher efficacy (Penecilla et al. 2011). Furthermore, for respiratory processes, people were covered with a blanket, inhaling the vapors given off by certain plants when water is boiling. If a person is suffering from relapse, it inhales the vapor of Cordia dichotoma (G). Frost, commonly known as "anonang," when at boiling point. However, as the paste was done using the plant part, the application was applied directly to the affected area. Sometimes the herbal plant is mixed with vinegar, oil, or salt. It was shown that almost all of the modes of preparations documented used mono-herbal recipes (Penecilla et al. 2011).

On the other hand, the mode of applications can be done externally or internally. The medicinal plant's different preparations and application methods, both internal and external, are mostly diluted. Simultaneously, some remedies are prepared from fresh and dry plant parts (Ong et al. 2014). Therefore it was revealed in the treatment can be applied as a paste $(44 \%)$, decoction $(37 \%)$, crushed $(15 \%)$, eaten as raw $(2 \%)$, and used as washed (2\%), respectively. As shown in Figure 3, the external route of administration is evident rather than internal.

Furthermore, informants also confirmed that there is no standardized measurement of the dose of herbal remedies. The dose depends on the solely on the herbalist that prepares the herbs for medicinal purpose. Lack of standardization, precision, and agreement among informants on doses are some of the constraints of traditional medicinal plants in a given ailment.

\section{Use value}

Out of 74 collected medicinal plants, ten (10) from these seem to be the most well-known to the local inhabitants as indicated by their high use value (UV) (Table 3). The UV of the plants means species that are considered to be most important in the municipality based on their reports. Like Moringa oleifera Lam, Anona muricata L., and Blumea balsamifera ( L.) DC, Andrographis paniculata (Burm.f.) Nees., Plectranthus amboinicus (Lour.) Spreng., Artemisia vulgaris L. Senna alata (L.) Roxb., Cordia dichotoma ( G.) Forst, Lagerstroemia speciosa (L.) Pers., Centella abbreviata (A. Rich.) Nannf. were indigenous, common, and widely distributed. At the same time, M. oliefera is a plant that can easily be cultivated within unfavorable conditions believed to be potential for health and beauty products. All parts and components derived from the plant have been used to alleviate various ailments in traditional medicine. Wide availability makes it excellent potential for growth in the economy and health \& nutrition sector in a developing country. It is very rich in healthy antioxidant and bioactive compounds. It can cure skin infections and sores. $A$. muricata has been widely used as a source of chemically active metabolites due to their various curative properties and is thus considered as an excellent candidate to be used as complementary medicine. Extracts from the plant contain a high concentration of secondary class metabolite compounds, A. muricata have been shown to have promising compounds that can be utilized in the treatment of cancer. A. muricata plant extracts contain compounds that are particularly effective against cancer cells. and their potential to be integrated as one of the treatment options against cancer (Gavamukulya et al. 2014). B. balsamifera common medicinal plant widely distributed in open fields, grasslands, and waste areas, at low and medium altitudes. A very popular Philippine herbal plant used as medicine to treat anti-spasms, wounds, and cuts, rheumatism, antidiarrhea, colds, and coughs. It is also used for infected wounds, respiratory infections and stomach pains and very popular among people with kidney problems because of its diuretic qualities (Montealegre et al. 2017). It can be taken as an early afternoon tea to maintain a healthy urinary tract and helps flush uric acid as well. A. paniculata has been treating various diseases and which are highly showing preventative effects against ailments like liver damage, infection, hyperglycemia, cancer. It is also used as a medicinal remedy for stomach ache, fever, pain reduction, disorders of the intestinal tract (Nyeem et al. 2017) $P$. amboinicus, has therapeutic and nutritional properties attributed to its natural phytochemical compounds which are highly valued in the pharmaceutical industry. Besides, it has horticultural properties due to its aromatic nature and essential oil-producing capability (Arumugam et al. 2016). The leaves of the plant are often eaten raw or used as flavoring agents, or incorporated as ingredients in traditional food preparation.

Moreover, A. vulgaris has garnered the attention of researchers in the past few decades, and several research studies have investigated its biological effects, including antioxidant, anti-inflammatory, anticancer, hypolipidemic, and antimicrobial properties (Soon et al. 2019). S. alata is a medicinal herb distributed in tropical and humid regions. This plant is traditionally used to treat typhoid, diabetes, malaria, asthma, ringworms, tinea infections, scabies, blotch, herpes, and eczema. Different plant parts are reported in folk medicine as therapeutic substances to remediation diverse diseases and infections. The extracts and isolated compounds displayed pronounced pharmacological activities (Soon et al. 2019)

Various parts of C.dichotoma this plant, such as leaves, root, seed, bark, and fruit, have been reported for possessing immunomodulatory, antidiabetic, anthelmintic, anti-ulcer, anti-inflammatory, and analgesic activity (Hussain et al. 2013). Hence, medicinal species with the highest use-value were commonly used by the local inhabitants in traditional medicine and can be found and wildly distributed in their community and available when needed. Nonetheless, these species can be associated with 
conservation issues where this therapeutic medicinal species mentioned will suffer the most significant harvesting pressure (Macía et al. 2005).

\section{Informant consensus factor}

Informant Consensus Factor was calculated by using each of the disease categories. As shown in Table 4, the highest value of 1.0 obtained indicates that people use particular plants consistently in the category. Three medicinal plants with the Highest ICF category got the value of (1.0) was for Muscolo-skeletal (1.0), which was frequently used $J$. gendarussa by applying leaves on the forehead, Genito-urinary (1.0), was frequently used $L$. speciosa. For Eyes, Nose, Ears, Throat (1.0), C. abbreviata was used frequently to cure the diseases under this category. OB-Gynecology (0.98), and the frequently used plant species is $P$. cablin followed by illness in Gastrointestinal (0.94), was frequently used $A$. paniculata to treat stomach ache. These informant consensus values implied reasonable indications about particular species that serve specific health problems and medicinal plants for several health problems. Medicinal plants with higher informant consensus need to be seriously considered for further ethnopharmacological investigations. These are species widely applied by people, and they have been utilized for a long time.

\section{Fidelity level}

Fidelity plant species for specific diseases varied widely, ranging between $1 \%$ and $100 \%$ for the plant in the study area. The high fidelity level (FL) can imply that the most preferred plant species for a particular disease and the lowest indicates less-preferred species for treating specific treatment. High FL for particular plant species suggests that they might contain valuable phytochemical compounds with pharmacological effects that have to be proven scientifically. The maximum FL of $100 \%$ was obtained in A. paniculata and $P$. cablin, respectively. A. paniculata is an antibacterial agent capable of counteracting the ill effects of pathogenic microbes (Mishra et al. 2017;
Shirisha et al. 2013). The plant has the antimicrobial activity of aqueous leaf extract; and found to have an antibacterial effect against Bacillus subtilis and Streptococcus aureus. Extracts of A. paniculata have effectively shown activity against diarrhea connected with Escherichia coli infections (Mishra et al. 2013). The A. paniculata components, i.e., andrographolide and neoandrographolide showed comparable activity to loperamide (Imodium), the most common anti-diarrhea drug.

Moreover, previous studies showed that A. paniculata methanol extract could cure mild to moderately active ulcerative colitis (Nyeem et al. 2017). However, P. cablin is widely used in gastrointestinal disease and exterior syndromes, confirmed by both in vitro and in vivo studies (Chen et al. 2013; Mishra et al. 2013; Junren et al. 2021). To exploit this, traditional medicine that adequately fits modern drugs is used to treat specific ailments known as gastrointestinal and OB-Gynecology illnesses (Table 4).

Table 1. Demographic characteristics of respondents characterized by gender, age range, and education

\begin{tabular}{lc}
\hline Characteristics & Frequency \\
\hline Gender & 114 \\
Male & 236 \\
Female & \\
& \\
Age range & 53 \\
18-30 years old & 80 \\
$31-45$ years old & 130 \\
$46-60$ years old & 52 \\
$61-75$ years old & 35 \\
75 and above & \\
& \\
Education & 130 \\
Elementary & 116 \\
Secondary & 104 \\
Tertiary
\end{tabular}

Table 3. Plants in Malinao, Albay, Philippines with the highest use values $(\mathrm{N}=75)$, scientific name, number of use reports, number of categories, and main disease

\begin{tabular}{lcclc}
\hline Scientific name & $\begin{array}{c}\text { No. of use } \\
\text { reports }\end{array}$ & $\begin{array}{c}\text { No. of cate- } \\
\text { gories }\end{array}$ & Main disease & Use value \\
\hline Moringa oleifera Lam. & 110 & 4 & Wounds & 0.31 \\
Anona muricata L. & 95 & 4 & Cancer & 0.27 \\
Blumea balsamifera (L.) DC & 90 & 4 & Stomach ache & 0.26 \\
Cordia dichotoma G. Forst & 80 & 4 & Relapse & 0.23 \\
Lagerstroemia speciosa (L.) Pers & 60 & 4 & Stones & 0.17 \\
Artemisia vulgaris L. & 80 & 3 & Skin disease & 0.23 \\
Senna alata (L.) Roxb. & 75 & 3 & Ringworms & 0.21 \\
Centella abbreviata (A. Rich.) Nannf & 57 & 3 & Cancer sore & 0.16 \\
Andrographis paniculata (Burm.f.) Nees & 85 & 2 & Stomach ache & 0.24 \\
Plectranthus amboinicus (Lour.) Spreng & 78 & 2 & Colds & 0.22 \\
\hline
\end{tabular}


Table 2. Identification of the collected medicinal plants, including the family, scientific name, common name, habit, part used, medicinal values, and preparation and administration for the disease

\begin{tabular}{|c|c|c|c|c|c|c|}
\hline Family & Scientific name & Common name & Habit & Part used & Medicinal values & Preparation and administration \\
\hline \multirow[t]{2}{*}{ Acanthaceae } & Andrographis paniculata (Burm.f.) Nees & Essentiang buhay & Herb & Leaves & Stomach ache, Headache & Boil and drink decoction \\
\hline & Justicia gendarussa Burm.f. & Puli & Shrub & Leaves & Dislocation of bones, rheumatism & Apply as a paste in the infected area \\
\hline Amaryllidaceae & Proiphys amboinensis (L.) Herb. & Talionod & Herb & Leaves & Stomach ache, asthma, wounds & Apply as a paste in the affected area \\
\hline Anacardiaceae & Spondias pinnata (L.f.) Kurz & Lubas & Tree & Leaves & Anti-inflammatory, burns & Apply as a paste in the affected area \\
\hline Annonaceae & Anona muricata $\mathrm{L}$. & Guyabano & Tree & Leaves & $\begin{array}{l}\text { Anti-cancer, stomach acidity, } \\
\text { hypertension, cough }\end{array}$ & Boil and drink decoction \\
\hline Apiaceae & Centella abbreviata (A. Rich.) Nannf & Soro-soro & Herb & $\begin{array}{l}\text { Leaves, stem, } \\
\text { fruits }\end{array}$ & $\begin{array}{l}\text { Colds, infection in babies, cancer } \\
\text { sore }\end{array}$ & Drink decoction, apply as wash \\
\hline \multirow[t]{2}{*}{ Apocynaceae } & Voacanga globosa (Blanco) Merr. & Bayag Usa & Tree & Leaves, fruits & Hernia, anti-inflammatory & $\begin{array}{l}\text { Apply as a paste in an infected area with salt } \\
\text { and oil }\end{array}$ \\
\hline & Asclepsias curassavica $\mathrm{L}$. & De la de noche & Herb & Leaves & Anti-inflammatory, arthritis & Apply as a paste in the affected area \\
\hline Araceae & Caladium bicolor (Aiton) Vent & Natong na pula & Herb & Leaves & $\begin{array}{l}\text { Cough } \\
\text { Constipation }\end{array}$ & $\begin{array}{l}\text { Boil and drink decoction of young leaves } \\
\text { Apply as a paste in the affected area }\end{array}$ \\
\hline Asteraceae & Cyanthillium cinereum (L.) H.Rob. & $\begin{array}{l}\text { Kamandagan/ } \\
\text { Tagulinao }\end{array}$ & Herb & Leaves & $\begin{array}{l}\text { Kidney disorders, Urinary tract } \\
\text { infection }\end{array}$ & Boil and drink decoction \\
\hline Asparagaceae & $\begin{array}{l}\text { Sansevieria roxburghiana } \\
\text { (Schult. \& Schult.f.) Merr. }\end{array}$ & Dilang tigre & Ornamental & Leaves & Skin diseases & Apply as a paste in the affected area \\
\hline Balsaminaceae & Impatiens balsamina $\mathrm{L}$. & Rangga & Grass & Leaves & $\begin{array}{l}\text { Goiter, arthritis, burns, insects bite, } \\
\text { boils }\end{array}$ & Apply as a paste in the affected area \\
\hline \multirow[t]{2}{*}{ Boraginaceae } & Ehretia microphylla Lam. & Tsaang gubat & Herb & Leaves & Abdominal pain & Drink decoction \\
\hline & Cordia dichotoma G. Forst & Anonang & Shrub & Leaves & $\begin{array}{l}\text { Shingles, cough, headache } \\
\text { Relapse }\end{array}$ & $\begin{array}{l}\text { Leaves paste in the affected area } \\
\text { Paste heated leaves on the forehead }\end{array}$ \\
\hline Burseraceae & Canarium ovatum Engl. & Pili & Tree & Seeds & Indigestion, insect bites, skin allergies & Extracts paste in the affected area \\
\hline Caricaceae & Carica papaya $\mathrm{L}$. & Tapayas & Tree & $\begin{array}{l}\text { Leaves, fruits, } \\
\text { barks }\end{array}$ & Constipation & Freshly eaten \\
\hline \multirow[t]{6}{*}{ Compositae } & Blumea balsamifera ( L.) DC & Lakad bulan & Shrub & Leaves & $\begin{array}{l}\text { Headache } \\
\text { Skin disease } \\
\text { Rheumatism }\end{array}$ & $\begin{array}{l}\text { Apply crushed leaves on the forehead } \\
\text { Extract paste directly on wounds } \\
\text { Crushed leaves and apply as a paste }\end{array}$ \\
\hline & Gynura procumbens (Lour.) Merr. & Ashitaba & Herb & Leaves & $\begin{array}{l}\text { Lower blood pressure, blood sugar, } \\
\text { anticancer, ulcer }\end{array}$ & Eat raw leaves of the plant \\
\hline & Moringa oleifera Lam. & Kalunggay & Shrub & Leaves & $\begin{array}{l}\text { Lower blood pressure, skin disease, } \\
\text { wounds, antibacterial }\end{array}$ & $\begin{array}{l}\text { Boil and drink decoction, } \\
\text { Paste the extract to the affected area }\end{array}$ \\
\hline & Artemisa vulgaris $\mathrm{L}$. & Artemisa & Herb & Leaves & $\begin{array}{l}\text { Expectorants, skin disease, scabies, } \\
\text { eczema, wounds }\end{array}$ & $\begin{array}{l}\text { Boil and drink decoction, } \\
\text { Crushed leaves and apply as a paste }\end{array}$ \\
\hline & Ageratum conyzoides (L.) L. & Bulak manok & Grass & Leaves & Wounds & Crushed leaves and apply as a paste \\
\hline & $\begin{array}{l}\text { Chromolaena odorata (L.) R.M.King \& } \\
\text { H.Rob. }\end{array}$ & Mansi-pansi & Herb & Leaves & Wounds & Paste the extract to the affected area \\
\hline
\end{tabular}




\begin{tabular}{|c|c|c|c|c|c|c|}
\hline Crassulaceae & Bryophyllum pinnatum (Lam) Oken & Aritana & Herb & Leaves & Athlete's foot, boils, arthritis & Crushed leaves and apply as a paste \\
\hline \multirow[t]{4}{*}{ Euphorbiaceae } & Euphorbia hirta Linn & Tawa-tawa & Herb & Whole plant & Dengue fever, sore eyes, cataract & $\begin{array}{l}\text { Boil and drink decoction, paste extract in the } \\
\text { affected area }\end{array}$ \\
\hline & Jatropha curcas L. & Tuba & Shrub & Leaves & Rheumatism, sprain, cough & Crush and apply as a paste \\
\hline & Croton tiglium $\mathrm{L}$. & Tuble & Shrub & Seeds & Eczema, rashes & $\begin{array}{l}\text { Extraction of oil from the seed is used and } \\
\text { applied to the affected area. }\end{array}$ \\
\hline & Manihot esculenta Crantz & Kamoteng kahoy & Shrub & Leaves & Diarrhea & Drink powdered leaves \\
\hline \multirow[t]{4}{*}{ Fabaceae } & Crotalaria incana $\mathrm{L}$. & Mani-mani & Herb & Seeds & Skin disease & Apply as paste \\
\hline & Senna alata (L.) Roxb. & Kurukasitas & Herb & Leaves & Ringworms, fungus infection & Crush leaves and paste to the affected area \\
\hline & Mimosa pudica $\mathrm{L}$. & Makahiya & Grass & Leaves & Toothache, insomnia & Boil and drink decoction \\
\hline & Tamarindus indica $\mathrm{L}$. & Sampalok & Tree & Leaves & Aromatic bath, laxative, fever & Boil and drink decoction \\
\hline \multirow[t]{8}{*}{ Lamiaceae } & Pogostemon cablin (Blanco) Benth & Cadlum & Herb & Leaves & $\begin{array}{l}\text { Anti-inflammatory, arthritis, } \\
\text { rheumatism }\end{array}$ & Apply as paste \\
\hline & Vitex negundo L. & Lagundi & Tree & Leaves & $\begin{array}{l}\text { High fever, cough, stomach ache, } \\
\text { asthma }\end{array}$ & Boil and drink decoction for steam inhalation \\
\hline & Mentha arvensis $\mathrm{L}$. & Herba Buena & Herb & Leaves & Headache & Apply as paste \\
\hline & & & & & Cancer, colds & Boil and drink decoction \\
\hline & Gmelina arborera Roxb & Gmelina & Tree & Leaves & Cough, ulcer & Boil and drink decoction \\
\hline & Ocimum tenuiflorum $\mathrm{L}$. & Kamangkaw & Herb & Leaves & Stomach ache, fever, diarrhea & Boil and drink decoction \\
\hline & Plectranthus amboinicus (Lour.) Spreng & Oregano & Herb & Leaves & Colds, abdominal pain & Boil and drink decoction \\
\hline & Plectranthus scutellarioides (L.) R.Br. & Mayana & Herb & Leaves & Fresh wounds & Crushed and apply as a paste \\
\hline Leguminosae & Lablab purpureus (L.) Sweet & Bataw na pula & Shrub & Leaves & Stomach ache & Boil seeds and eat \\
\hline Lauraceae & Persea americana Mill & Avocado & Tree & Leaves & $\begin{array}{l}\text { stomach ache, cough, ulcer, } \\
\text { diarrhea }\end{array}$ & Boil and drink decoction \\
\hline Lythraceae & Lagerstroemia speciosa (L.) Pers & Banaba & Tree & $\begin{array}{l}\text { Leaves, } \\
\text { barks }\end{array}$ & $\begin{array}{l}\text { Kidney, stomach ache, Urinary } \\
\text { Tract Infection, gallstone }\end{array}$ & Boil and drink decoction \\
\hline \multirow[t]{4}{*}{ Malvaceae } & Corchorus capsularis L & Saluyot & Shrub & Leaves & Bowel constipation, cyst, cancer & Boil and drink decoction \\
\hline & Theobroma cacao $\mathrm{L}$. & Cacao & Tree & Seeds & $\begin{array}{l}\text { Eczema, dry skin, } \\
\text { Cough }\end{array}$ & $\begin{array}{l}\text { Apply paste in the affected area } \\
\text { Boil and drink decoction }\end{array}$ \\
\hline & Hibiscus rosasinensis $\mathrm{L}$. & $\begin{array}{l}\text { Gumamela/ } \\
\text { Kayanga }\end{array}$ & Ornamental & $\begin{array}{l}\text { Flowers, } \\
\text { leaves }\end{array}$ & Boils & Paste pounded leaves in the affected area \\
\hline & Urena lobata $\mathrm{L}$. & Baranggot & Shrub & Flowers & Boils & $\begin{array}{l}\text { Crushed and apply in the affected area as a } \\
\text { paste }\end{array}$ \\
\hline Melastomaceae & Melastoma malabathricum $\mathrm{L}$. & Tungaw-tungaw & Shrub & Fruits & Cough & Eat raw, boil, and drink the decoction \\
\hline Meliaceae & Sandoricum koetjape (Burm.f.) Merr. & Santol & Tree & Leaves & Colds & Extract and drink the decoction \\
\hline Menispermaceae & Tinospora sp. & Makabuhay & Tree & Stem & Scabies, ulcer & Crushed leaves and paste in the affected area \\
\hline \multirow[t]{4}{*}{ Moraceae } & Ficus nota (Blanco) Merr & Tabog-tabog & Tree & Leaves & Sprain & Paste extract in the affected area \\
\hline & Ficus benjamina Linn. & Balite & Tree & Sap & Sprain & Paste extract in the affected area \\
\hline & Ficus pseudopalma Blanco & Lubi-lubi & Shrub & Leaves & Hypertension, & Boil and drink decoction \\
\hline & Ficus fistulosa Reinwardt ex Blume & Hayupit & Shrub & Seeds & Insect bites & Crushed leaves \\
\hline Myrtaceae & Psidium guajava $\mathrm{L}$. & Baya was & Tree & Leaves & Diarrhea, wounds, stomach ache & Boil and drink decoction \\
\hline Oleaceae & Jasminum sambac (L.) Aiton & Sampaguita & Shrub & Leaves & Wounds & Apply paste in the affected area \\
\hline Oxalidaceae & Averrhoa bilimbi Linn & $\mathrm{Iba}$ & Tree & Leaves & Mumps & Apply paste in the affected area \\
\hline
\end{tabular}




\begin{tabular}{|c|c|c|c|c|c|c|}
\hline \multirow[t]{2}{*}{ Phyllanthaceae } & Phyllanthus niruri L. & Likod-likod & Herb & Leaves & Tonsillitis, kidney disease, wounds & Boil and drink decoction \\
\hline & Antidesma ghaesembilla Gaertn & Bignay & Tree & Leaves & Cough, kidney, colds, diabetes & Boil and Drink decoction \\
\hline \multirow[t]{2}{*}{ Piperaceae } & Piper betle L. & Buyo & Herb & Leaves & $\begin{array}{l}\text { Headache, sprain, } \\
\text { Colds }\end{array}$ & $\begin{array}{l}\text { Paste a cool compress } \\
\text { Boil and drink decoction }\end{array}$ \\
\hline & Peperomia pellucida L. Kunth & Pansit-pansit & Herb & Leaves & Diarrhea, kidney problem & Boil and Drink decoction \\
\hline \multirow[t]{2}{*}{ Poaceae } & Imperata cylindrica $($ L.) Raeusch & Gugon & Grass & Flowers & Kidney, colds, urinary tract infection & Boil and drink decoction \\
\hline & Cymbopogon schoenanthus (L.) Spreng & Tanglad & Herb & Leaves & $\begin{array}{l}\text { Hypertension, colds, stomach ache, } \\
\text { wounds }\end{array}$ & Boil and Drink decoction \\
\hline \multirow[t]{3}{*}{ Rubiaceae } & Ixora coccinea $\mathrm{L}$. & Santan & Ornamental & Leaves & Wounds & Crushed leaves \\
\hline & Mussaenda frondosa $\mathrm{L}$. & Tawa-tawa & Shrub & Leaves & Dysmenorrhea & Apply as a paste in the affected area \\
\hline & Morinda umbellata Linn. & Nino & Tree & Leaves & Anti-inflammatory & Apply as a paste in the affected area \\
\hline \multirow[t]{2}{*}{ Solanaceae } & Capsicum anuum $\mathrm{L}$. & Lada & Herb & Leaves & Arthritis & Crushed leaves paste in the affected area. \\
\hline & Datura metel Linn & Kalampunay & Shrub & Leaves & Headache, abdominal pain & Apply as a paste in the affected area \\
\hline \multirow[t]{3}{*}{ Verbenaceae } & Premna odorata Blanco & Adgaw & Tree & Leaves & Headlice, cough, fever, wounds & Paste crushed leaves on the affected area. \\
\hline & Stachytarpheta jamaicensis (L.) Vahl & $\begin{array}{l}\text { Talagtipot/ } \\
\text { kandikandilaan }\end{array}$ & Shrub & Leaves & Cuts, wounds & Paste crushed leaves on the affected area. \\
\hline & Vitex negundo Linn & Lagundi & Shrub & Leaves & $\begin{array}{l}\text { Cough, stomach ache, asthma, sore } \\
\text { throat }\end{array}$ & Boil and drink decoction \\
\hline Xanthorrhoeaceae & Aloe vera (L.) Burm. f & Aloe vera & Shrub & Leaves & Falling hair & Sap apply to scalp \\
\hline \multirow[t]{4}{*}{ Zingiberaceae } & Alpinia elegans (C.Presl) K.Schum & Tagbak & Shrub & Leaves & Coughs & Fruits should be eaten raw \\
\hline & Curcuma longa Linn & Luyang dilaw & Herb & Leaves & Cancer, swelling, arthritis & Drink decoction \\
\hline & Hedychium coronarium J.Koenig & Kamia & Shrub & Leaves & Cough & Drink decoction \\
\hline & Kaempferia galanga $\mathrm{L}$ & Dusol & Shrub & Leaves & Anti-inflammatory, stomach ache & Apply paste in the affected area \\
\hline
\end{tabular}

Table 4. Plants in Malinao, Albay, Philippines arranged in disease category, most frequently used plants, common name, number of reports used, Informant Consensus Factors (ICF) and Fidelity Level (FL)

\begin{tabular}{|c|c|c|c|c|c|c|}
\hline Disease category & Most frequently used plants & Common name & No. of used reports & No. of taxa & ICF & FL \% \\
\hline Gastro-intestinal & Andrographis paniculata (Burm.f.) Nees & Essentiang buhay & 300 & 19 & 0.94 & $88.89 \%$ \\
\hline Skin Disease & Senna alata $($ L.) Roxb. & Kurukasitas & 165 & 21 & 0.88 & $100.00 \%$ \\
\hline Respiratory & Plectranthus amboinicus (Lour.) Spreng & Oregano & 120 & 14 & 0.89 & $51.28 \%$ \\
\hline Cardio-metabolic & Anona muricata $\mathrm{L}$. & Guyabano & 90 & 7 & 0.93 & $42.11 \%$ \\
\hline Musculo-skeletal & Justicia gendarussa Burm.f & Puli & 250 & 2 & 1 & $93.75 \%$ \\
\hline Genito-Urinary & Lagerstroemia speciosa (L.) Pers & Banaba & 150 & 3 & 1 & $46.51 \%$ \\
\hline OB-Gynecology & Pogostemon cablin (Blanco) Benth & Cadlum & 60 & 2 & 0.98 & $100.00 \%$ \\
\hline Eyes, Ears, Nose, Throat & Centella abbreviata (A. Rich.) Nann & Soro-soro & 30 & 1 & 1 & $43.86 \%$ \\
\hline Injury and Poisons of external causes & Jatropha curcas L & Tuba & 70 & 16 & 0.78 & $97.22 \%$ \\
\hline
\end{tabular}




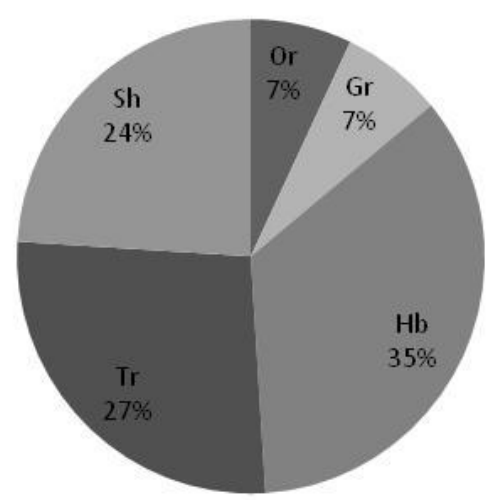

Figure 2. Characteristics of plants used for traditional medicine by inhabitants of the selected barangays in Malinao Albay. $\mathrm{Hb}$, herbs; Tr, trees; Sh, shrub; Or, ornamental; and Gr, grass

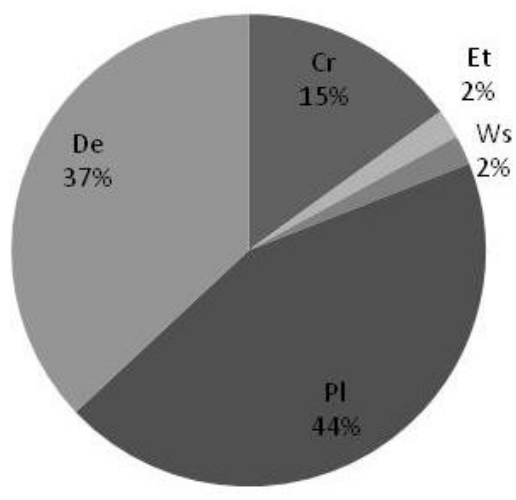

Figure 4. Mode of preparation of therapeutic plants used by the inhabitants of the selected barangays in Malinao Albay. De, decoction; $\mathrm{Pl}$, paste; $\mathrm{Cr}$, crushed; Et, eaten and Ws, washed.

In conclusion, this study showed the prevailing ethnobotanical knowledge on the traditional uses of plantbased medicine in treating certain diseases and health problems among the local inhabitants in the Municipality of Malinao, given the fact that they have scarce health facilities in the community. The significance of this rich ethnobotanical knowledge has furnished novel information which could provide the basis for new avenues in future quantitative ethnobotanical investigations to improve the utilization of herbal plants from global perspectives. The data from this study can also serve as the basis for conserving the local medicinal flora. It is recommended that the local government and community's proper management initiatives protect the Mt. Malinao biodiversity. However, extensive research is encouraged to continue exploring medicinal plants' potentials to treat various illnesses against expensive medicines.

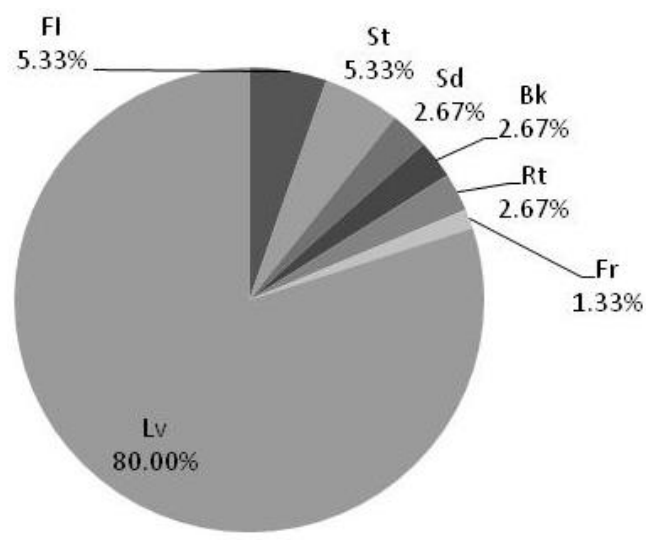

Figure 3. Plant Parts used by the inhabitants for traditional medicine in selected barangays in Malinao Albay. Parts used include Lv, leaves; Fl, flower; St, stem; Sd, seed; Bk, bark; Rt, roots; and Fr, fruit.

\section{ACKNOWLEDGEMENTS}

The first author thanks the Commission on Higher Education for the scholarship grant, the Thomasian Angiosperm Phylogeny and Barcoding Group (TAPBG), and UST-Research Center for the Natural and Applied Sciences (RCNAS) for their assistance and support. Grecebio Jonathan D. Alejandro thanks DOST-Philippine Council for Health Research and Development for the research grant.

\section{REFERENCES}

Abe R, Ohtani K. 2013. An ethnobotanical study of medicinal plants and traditional therapies on Batan Island, the Philippines. J Ethnopharmacol 145 (2): 554-565. DOI: 10.1016/j.jep.2012.11.029.

Ahmad M, Sultana S, Fazl-i-Hadi S, Ben Hadda T, Rashid S, Zafar M, Yaseen G. 2014. An ethnobotanical study of medicinal plants in high mountainous region of Chail valley (District Swat-Pakistan). J Ethnobio Ethnomed 10 (1): 1-18. DOI: 10.1186/1746-4269-10-36.

Alexiades M. 1996. Collecting ethnobotanical data: an introduction to basic concepts and techniques. In: Alexiades $M$ (ed.). Selected Guideline for Ethnobotanical Research a Field Manual. The New York Botanical Garden, New York.

Arumugam G, Swamy MK, Sinniah UR. 2016. Plectranthus amboinicus (Lour.) Spreng: botanical, phytochemical, pharmacological and nutritional significance. Molecules 21 (4): 369. DOI: 10.3390/molecules21040369.

Awoyemi OK, Abdulkarim IA, Ewa EE, Aduloju AR. 2012. Ethnobotanical assessment of herbal plants in South-Western Nigeria. Acad Res Int 2: 50-57.

Aziz MA, Adnan M, Khan AH, Shahat AA, Al-Said MS, Ullah R. 2018. Traditional uses of medicinal plants practiced by the indigenous communities at Mohmand Agency, FATA, Pak J Ethnobiol Ethnomed 14 (1): 1-16. DOI: 10.1186/s13002-017-0204-5.

Balangcod T, Balangcod AK. 2011. Ethnomedical knowledge of plants and healthcare practices among the Kalanguya tribe in Tinoc, Ifugao, Luzon, Philippines. Indian J Tradit Knowl 10 (2): 227-238.

Birendra MB, Gauchan D, Chhetri G. 2015. An ethnobotanical study of medicinal plants used by ethnic people in Parbat District of Western Nepal. J Ethnopharmacol 165: 103-17. DOI: 10.1016/j.jep.2014.12. 057. 
Birhane E, Aynekulu E, Mekuria W, Endale D. 2011. Management, use and ecology of medicinal plants in the degraded drylands of Tigray, Northern Ethiopia. J Hortic For 3 (2): 32-41.

Braidotti R, Charkiewicz E, Hausler S, Wieringa S. 1994. Women, the Environment and Sustainable Development: Towards a Theoretical Synthesis. Zed Books Ltd., London.

Chen M, Zhang J, Lai Y, Wang S, Li P, Xiao J, Wang Y. 2013. Analysis of Pogostemon cablin from pharmaceutical research to market performances. Expert Opin Investig Drugs 22 (2): 245-257. DOI: 10.1517/13543784.2013.754882.

Dapar MLG, Alejandro GJD, Meve U, Liede-Schumann S. 2020 Quantitative ethnopharmacological documentation and molecular confirmation of medicinal plants used by the Manobo Tribe of Agusan del Sur, Philippines. J Ethnobiol Ethnomed 16 (1): 1-60. DOI: 10.1186/s13002-020-00363-7.

De Guzman GQ, Nacua AE, Belgica TH, Clemente KJ, Alejandro GJ. 2014. Assessment, inventory and ethnobotanical survey of medicinal plants in Mount Malinao (Albay, Philippines). Intl J Pharm 5 (3): 1014-1019.

Friedman J, Yaniv Z, Dafni A, Palewitch D. 2006. A preliminary classification of the healing potential of medicinal plants, based on a rational analysis of an ethnopharmacological field survey among Bedouins in the Negev Desert, Israel. J Ethnopharm 16 (2-3): 275287. DOI: $10.1016 / 0378-8741(86) 90094-2$.

Gavamukulya Y, Abou-Elella F, Wamunyokoli F, Hae S. 2014 Phytochemical screening, antioxidant activity and in vitro anticancer potential of ethanolic and water leaves extracts of Annona muricata (Graviola). Asian Pac J Trop Med 7 (1): 355-363. DOI: 10.1016/S1995- 7645(14)60258-3.

Giday M, Teklehaymanot T. 2013. Ethnobotanical study of plants used in management of livestock health problems by Afar people of Ada'ar District, Afar Regional State, Ethiopia. J Ethnobiol Ethnomed 9: *. DOI: $10.1186 / 1746-4269-9-8$.

Heinrich M. 2000. Ethnobotany and its role in drug development. Phytother Res 14 (7): 479-488. DOI: 10.1002/1099-1573

Hussain N, Kakoti BB. 2013. Review on ethnobotany and phytopharmacology of Cordia dichotoma. J Drug Deliv Thera 3 (1). DOI: $10.22270 /$ jddt.v3i1.386.

Junren C, Xiaofang X, Mengting L, Qiuyun X, Gangmin L, Huiqiong Z, Cheng, P. 2021. Pharmacological activities and mechanisms of action of Pogostemon cablin Benth: a review. Chin Med 16 (1): 1-20. DOI: 10.1186/s13020-020-00413-y

Khan I, AbdElsalam NM, Fouad H, Tariq A, Ullah R, Adnan M. 2014 Application of ethnobotanical indices on the use of traditional medicines against common diseases. Evid-based Compl Altern Med. DOI: $10.1155 / 2014 / 635371$.

Knittel-Weber C, Knittel U. 1990. Petrology and genesis of the volcanic rocks on the eastern flank of Mount Malinao, Bicol Arc (southern Luzon, Philippines). J Southeast Asian Earth Sci 4 (4): 267-280. DOI 10.1016/0743-9547(90)90002-U

Kumar S, Kumar R, Khan A. 2011. Medicinal plant resources: manifestation and prospects of life-sustaining healthcare system. Cont J Biol Sci 4 (1): 19-29.

Macía MJ, García E, Vidaurre PJ. 2005. An ethnobotanical survey of medicinal plants commercialized in the markets of $\mathrm{La} \mathrm{Paz}$ and $\mathrm{E}$ Alto, Bolivia. J Ethnopharmacol 97 (2): 337-350. DOI: 10.1016/j.jep.2004.11.022.

Mishra MP, Rath S, Swain SS, Ghosh G, Das D, Padhy RN. 2017. In vitro antibacterial activity of crude extracts of 9 selected medicinal plant against UTI causing MDR bacteria. J King Saud Univ Sci 29 (1): 84 95. DOI: $10.1016 /$ j.jksus.2015.05.007.

Montealegre C, de Leon R. 2017 Effect of Blumea balsamifera extract on the phase and morphology of calcium oxalate crystals. Asian J Urol 4 (4): 201-207. DOI: 10.1016/j.ajur.2016.08.009

Mukherjee PK. 2019. Quality Control and Evaluation of Herbal Drugs: Evaluating Natural Products and Traditional Medicine. Elsevier, Nederland. DOI: 10.1016/B978-0-12-813374-3.00016-8.
Newman DJ, Cragg GM. 2012. Natural products as source of new drugs over the 30 years from 1981 to 2010 . J Nat Prod 75 (3): 331-335. DOI: $10.1021 / \mathrm{np} 200906 \mathrm{~s}$.

Nyeem MAB, Mannan MA, Nuruzzaman M, Kamrujjaman K.M, Das SK. 2017. Indigenous king of bitter (Andrographis paniculata): A review. J Med Plants Stud 5 (2): 318-324.

Obico JJA, Ragragio EM. 2014. A survey of plants used as repellents against hematophagous insects by the Ayta people of Porac, Pampanga province, Philippines. Philipp Sci Lett 7 (1): 179-86.

Odchimar NMO, Nuñeza OM, Uy M, Senarath WTPSK. 2017. Ethnobotany of medicinal plants used by the Talaandig Tribe in Brgy. Lilingayon, Valencia City, Bukidnon, Philippines. Asian J Bio Life Sci 6 (1): 358-364

Ong HG, Kim YD. 2014. Quantitative ethnobotanical study of the medicinal plants used by the Ati Negrito indigenous group in Guimaras Island, Philippines. J Ethnopharmacol 157: 228-242. DOI: 10.1016/j.jep.2014.09.015.

Prasad AD, Shyma TB, Raghavendra MP. 2013. Informant consensus factor and antimicrobial activity of ethno medicines used by the tribes of Wayanad district, Kerala. Afr J Microbiol Res 7 (50): 5657-5663. DOI: 10.5897/AJMR12.1215.

Pelser PB, Barcelona JF, Barcelona, Nickrent DL (eds). 2011 onwards. Co's Digital Flora of the Philippines. www.philippineplants.org

Penecilla GL, Magno CP. 2011. Antibacterial activity of extracts of twelve common medicinal plants from the Philippines. J Med Plants Res 5 (16)3975-3981.

Schultz F, Anywar G, Wack B, Quave CL, Garbe LA. 2020. Ethnobotanical study of selected medicinal plants traditionally used in the rural Greater Mpigi region of Uganda. J Ethnopharmacol 28 (256): 112742 . DOI: $10.1016 /$ j.jep.2020.112742.

Shirisha K, Mastan M, 2013. Andrographis paniculata and its bioactive phytochemical constituents for oxidative damage: a systematic review. Pharmacophore 4 (6): 212-229.

Singh A, Kumar A, Tewari D. 2012. An ethnobotanical survey of medicinal plants used in Terai forest of Western Nepal. J Ethnobiol Ethnomed 8: 19. DOI: 10.1186/1746-4269-8-19.

Sofowora A, Ogunbodede E, Onayade A. 2013. The role and place of medicinal plants in the strategies for disease prevention. Afr J Tradit Compl Alternat Med 10 (5): 210-229. DOI: 10.4314/ajtcam.v10i5.2.

Soon L, Ng PQ, Chellian J, Madheswaran T, Panneerselvam J, Gupta G, Chellappan DK. 2019. Therapeutic potential of Artemisia vulgaris: An insight into underlying immunological mechanisms. J Environ $\begin{array}{lllll}\text { Pathol Toxicol } & \text { Oncol } 38 & \text { (3): } & \text { DOI: }\end{array}$ 10.1615/JEnvironPatholToxicolOncol.2019029397.

Stuartxchange. 2019. Lists of Philippine Herbal Medicinal Plants. http://www.stuartxchange.org/CompleteList.

Suba MD, Arriola AH, Alejandro GJD. 2019. A checklist and conservation status of the medicinal plants of Mount Arayat National Park, Pampanga, Philippines. Biodiversitas 20 (4): 1034-1041. DOI: 10.13057/biodiv/d200414.

Tantengco OAG, Condes MLC, Estadilla HHT, Ragragio EM. 2018. Ethnobotanical survey of medicinal plants used by Ayta communities in Dinalupihan, Bataan, Philippines. Pharmacogn J 10 (5): 859-870.

The Plant List. 2013. Version 1.1. http://www.theplantlist.org

Tongco MD. 2013. Purposive sampling as a tool for informant selection. Ethnobot Res Appl 5: 147-158.

Tropicos. 2019. Missouri Botanical Garden. http://www.tropicos.org

Trotter RT, Logan MH. 1986. Informant consensus: A new approach for identifying potentially effective medicinal plants In: Etkin NL (ed.). Plants in Indigenous Medicine and Diet. Redgrave Publishing Company, Bedford Hill, NY.

WHO. 2020. ICD-11 for Mortality and Morbidity Statistics Version: 09/2020. World Health Organization, Geneva.

WHO. 2014. Traditional Medicine, Fact Sheet N 134. World Health Organization, Geneva.

Yuan H, Ma Q, Ye L, Piao G. 2016. The traditional medicine and modern medicine from natural products. Molecules 21 (5): 559. DOI: $10.3390 /$ molecules 21050559 . 